\title{
"The mediating role of emotional intelligence in the employees performance"
}

\begin{tabular}{|c|c|}
\hline AUTHORS & $\begin{array}{l}\text { Arief Tukiman Hendrawijaya (D https://orcid.org/0000-0003-1765-9242 } \\
\text { Tatang Ary Gumanti (D https://orcid.org/0000-0003-1751-2590 } \\
\text { Sasongko } \\
\text { Zarah Puspitaningtyas (D http://orcid.org/0000-0002-1616-4822 }\end{array}$ \\
\hline ARTICLE INFO & $\begin{array}{l}\text { Arief Tukiman Hendrawijaya, Tatang Ary Gumanti, Sasongko and Zarah } \\
\text { Puspitaningtyas (2018). The mediating role of emotional intelligence in the } \\
\text { employees performance. Problems and Perspectives in Management, 16(1), 145- } \\
\text { 154. doi:10.21511/ppm.16(1).2018.14 }\end{array}$ \\
\hline DOI & http://dx.doi.org/10.21511/ppm.16(1).2018.14 \\
\hline RELEASED ON & Thursday, 22 February 2018 \\
\hline RECEIVED ON & Monday, 18 September 2017 \\
\hline ACCEPTED ON & Wednesday, 31 January 2018 \\
\hline LICENSE & $\begin{array}{l}(\mathrm{cc}) \overline{\mathrm{EY}-\mathrm{NC}} \\
\text { This work is licensed under a Creative Commons Attribution-NonCommercial } 4.0 \\
\text { International License }\end{array}$ \\
\hline JOURNAL & "Problems and Perspectives in Management" \\
\hline ISSN PRINT & $1727-7051$ \\
\hline ISSN ONLINE & $1810-5467$ \\
\hline PUBLISHER & LLC "Consulting Publishing Company "Business Perspectives" \\
\hline FOUNDER & LLC “Consulting Publishing Company "Business Perspectives" \\
\hline
\end{tabular}

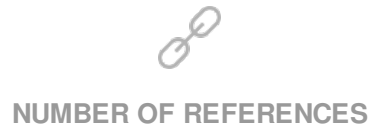

44

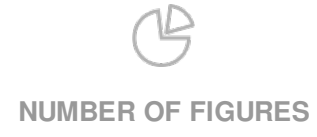

2
NUMBER OF TABLES

3

(C) The author(s) 2023. This publication is an open access article. 


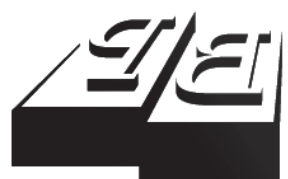

BUSINESS PERSPECTIVES

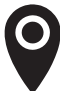

LLC "CPC "Business Perspectives" Hryhorii Skovoroda lane, 10, Sumy, 40022, Ukraine

www.businessperspectives.org

Received on: $18^{\text {th }}$ of September, 2017 Accepted on: $31^{\text {st }}$ of January, 2018

(c) Arief Tukiman Hendrawijaya, Tatang Ary Gumanti, Sasongko, Zarah Puspitaningtyas, 2018

Arief Tukiman Hendrawijaya, Ph.D. degree in Public Administration, Faculty of Teacher Training and Eductaion, Jember University, Indonesia.

Tatang Ary Gumanti, Ph.D. degree in Finance, Faculty of Economics and Business, Jember University, Indonesia.

Sasongko, Ph.D. degree in Public Administration, Faculty of Social and Political Science, Jember University, Indonesia.

Zarah Puspitaningtyas, Ph.D. degree in Management, Faculty of Social and Political Science, Jember University, Indonesia.

\section{(ㄷ)(1) $(9$}

This is an Open Access article, distributed under the terms of the Creative Commons Attribution-NonCommercial 4.0 International license, which permits re-use, distribution, and reproduction, provided the materials aren't used for commercial purposes and the original work is properly cited.
Arief Tukiman Hendrawijaya (Indonesia), Tatang Ary Gumanti (Indonesia),

Sasongko (Indonesia), Zarah Puspitaningtyas (Indonesia)

THE MEDIATING ROLE OF

EMOTIONAL INTELLIGENCE IN THE EMPLOYEES PERFORMANCE

\begin{abstract}
This study investigates the mediating effect of emotional intelligence on the relationship between motivation, compensation, satisfaction, work climate and employees' performance. The sample consists of 96 field officials who were the government employees specializing in coping with the eradication of Dengue Hemorrhagic Fever (DHF) in the district of Jember, Indonesia. Results using path analysis reveal that all examined variables positively and significantly affect employees' performance. The study finds that emotional intelligence mediates the relationship of work motivation, compensation, work satisfaction, and work climate with employees' performance.
\end{abstract}

\section{Keywords}

motivation, compensation, satisfaction, work climate, emotional intelligence, performance

\section{JEL Classification $\quad$ M52, M55, O15}

\section{INTRODUCTION}

Numerous studies have been devoted to examine the relationship between motivation, compensation, satisfaction, work climate, and the performance of employees (Manzoor, 2011; Munawaroh et al., 2013; Khan et al., 2012; Muda et al., 2014; Obicci, 2015; Elqadri et al., 2015). Other studies focus on examining the relationship between emotional intelligence and employees' performance (Sy et al., 2006; Rizal et al., 2014; Diab \& Aljouni, 2012; Chandrasekar, 2011; Vratskikh et al., 2016; Himanshu et al., 2017). The current study analyzes the mediating effect of emotional intelligence on the relationship between motivation, compensation, satisfaction, work climate, and the performance of employees. This study is considered to be different compared to previous studies as it employs government employees with specific task. That is, the samples are government employees assigned specifically to eradicate the Dengue Hemorrhagic Fever (DHF) in the district of Jember, East Java Province, Indonesia.

The DHF is one particular disease, which is endemic in the district of Jember in which throughout the years its emergence is constantly rising. The number of DHF patients by the end of 2015 were 905 persons. Jember has a total of $3,293.34 \mathrm{~km}^{2}$ and as of 2016, it has a population of more than 2.5 million with a density of 787.47 people $/ \mathrm{km}^{2}$. Insufficient human resource, either in terms of quality or quantity, particularly the field officials, is believed to be the main cause of this problem (Jember Department of Health Affairs, 2016). The effort devoted to dealing with the disease in Jember district actually has been set out in the Regulatory Policy of Jember Regency, No. 188.45/222/012/2015. However, the government oftentimes faced several issues upon preventing and overcoming the disease. Those issues could probably result from the policy factors themselves (government, public, other 
health institutions) and also external factors (social environment). Nevertheless, one may argue that the issue occurred due to the mismatch between what is expected and what can be done by the field officials.

Evaluated from the number of officials, the field officials were limited in number when dealing with DHF or, simply put, they could not keep up with the required area coverage. This has been really influential to their performance, the indicators of which can be seen from the number of DHF patients, nearly reaching 1,000 persons. The prevention of DHF, which needs serious concern from the field officials, has to focus more on the area or region with dense population. The field officials are the component of human resource holding crucial role in improving task accomplishment. Thus, understanding what factors determine the field officials' performance is important not only for the department of health affairs, but also for other parties. The extent of government's program success is determined by the involvement of field officials in particular program (Caldwell \& Spinks, 1993). If the field officials possess high work motivation, their work performance will also peak, leading to successful prevention of DHF.

Some factors have been known to be related to the performance of employees. These include work motivation (Shahzadi et al., 2014; Zameer et al., 2014), compensation (Saeed et al., 2013; Elqadri et al., 2015), work satisfaction (Munawaroh et al., 2013; Muda et al., 2014), and work climate (Munawaroh et al., 2013; Muda et al., 2014). These four factors have been constantly determine the extent of employees' performance in various organizations. The current study examines the mediating role of emotional intelligence on the relationship of four previously mentioned variables with employees' performance.

Emotional intelligence is defined as the competence to recognize personal and others' feeling in motivating self and properly managing self-emotion or in taking part in social relationship (Goleman, 2006). Therefore, emotional intelligence refers to the competence in recognizing our own and others' feeling, the competence for self-motivation, and the competence to properly manage personal emotion and social relation. Dann (2002) states that emotional intelligence is a personal competence to deploy emotions so as to aid problem solving in living his life and working better and more effective. This is in the same wavelength with the idea of Abraham and Shanley (1997), which points out that individual with good emotional intelligence will gain optimal achievement and result.

Using a sample of 93 field officials specifically assigned to deal with the DHF, the study finds evidence that emotional intelligence significantly mediates the relationship between work motivation, compensation, work satisfaction, work climate and employees' performance. This finding suggests that emotional intelligence plays an important role in improving employees' performance.

The remaining of the paper is organized as follows. Section one presents the review of literature and the development of hypotheses. This is followed by research methods used in the study. Section three provides the results and discussion. Final section concludes the paper.

\section{LITERATURE REVIEW AND HYPOTHESES DEVELOPMENT}

\subsection{Work motivation, emotional intelligence, and performance}

Empirically, it is found that employees' work motivation affects their performance. Work motivation is a concept used by one to utilize his work potential within himself to initiate and direct his attitude in work performance (Gibson et al., 2009), thus it will affect employees' performance (Mindarti, 2005). Previous studies have found significant positive correlation between work motivation and work performance (Elqadri et al., 2015; Shahzadi, 2014; Rizal et al., 2014; Shafie et al., 2013). Zameer et al. (2014) and Manzoor (2011) have found that employees' motivation and organization performance are strongly related. In addition to the intertwinement between work motiva- 
tion and performance, work motivation also influences employees' performance and organization performance (Muda et al., 2014; Diab \& Ajlouni, 2012; Khan et al., 2012). Obicci (2015) has found that leader's work motivation determines the employees' work performance. Given the elaboration, the study proposes the following hypothesis:

\section{H1: Work motivation positively affects employees' performance.}

The success of performance upon achieving certain objective previously set is heavily dependent on presence of emotional intelligence among individuals with high motivation. If work motivation is present among employees and is supported by emotional intelligence, then work performance will excel (Patton, 1998). Sulthon (2009) underlines that work motivation denotes one's or group's attitude toward work performance and is supported by emotional intelligence. Work motivation is strongly tied to work passion. Work motivation fundamentally constitutes the actualization of intense performance, supported by impressive emotional intelligence (Suryabrata, 2006).

Purba (1999) opines that emotional intelligence represents the competence in emotional realm. It is the ability to cope with frustration, the ability to control emotion, optimism, and the ability to establish empathy with others. Individual with decent optimism poses fine emotional management and this will be influential for its performance. This is in line with Patton (1998) who advocates that effective emotion activation will lead to the success in establishing productive relation and achieving work satisfaction. Referring to the above elaboration, it becomes obvious that emotional intelligence will bridge work motivation and performance. Thus, the following hypothesis is proposed:

H2: Emotional intelligence mediates the relationship between work motivation and employees'performance.

\subsection{Compensation, emotional intelligence, and performance}

Nawawi (2005) advocates that compensation can be financial or non-financial. Although in general this very concept is mostly used in salary ad- ministration, compensation devoted to organization means appreciation or reward for employees who have made contribution to organization goals through their performance. Previous studies have revealed that compensation is strongly related to employees' performance (Saeed et al., 2013; Rizal et al., 2014; Elqadri et al., 2015). Other studies have found that fine compensation denotes motivation strategies to employees for improved performance (Yamoah, 2013). Based on these arguments, we propose the following hypothesis:

\section{H3: Compensation positively affects employees' performance.}

Compensation alludes to everything an employee receives as reward to his performance. Sufficient compensation which is supported by emotional intelligence or emotional maturity will boost employees to improve their performance as expected (Chermis, 1998). Moreover, it is believed that employees' dissatisfaction to compensation received will accrue negative attitude and poor emotional condition, eventually leading to decreased performance or even poor performance. Controlled finance keeping abreast with employees' performance can accrue fine emotional intelligence and improved productivity (Martin, 2000). Based on above explanation, it is clear that emotional intelligence will mediate the influence of compensation gain on performance. Thus, accordingly, the following hypothesis is formulated:

H4: Emotional intelligence mediates the relationship between compensation and employees' performance.

Work satisfaction, emotional intelligence, and performance

Work satisfaction represents one's attitude of an employee's profession. Someone with high work satisfaction will have positive attitude to his performance. On the other hand, someone who is not satisfied with his performance will have negative attitude to his performance (Robbins, 2002). As such, working condition denotes an activity which aims at gaining work satisfaction (Smith, 1975).

Dealing with work satisfaction, Luthans (2011) states that work satisfaction denotes pleasing or 


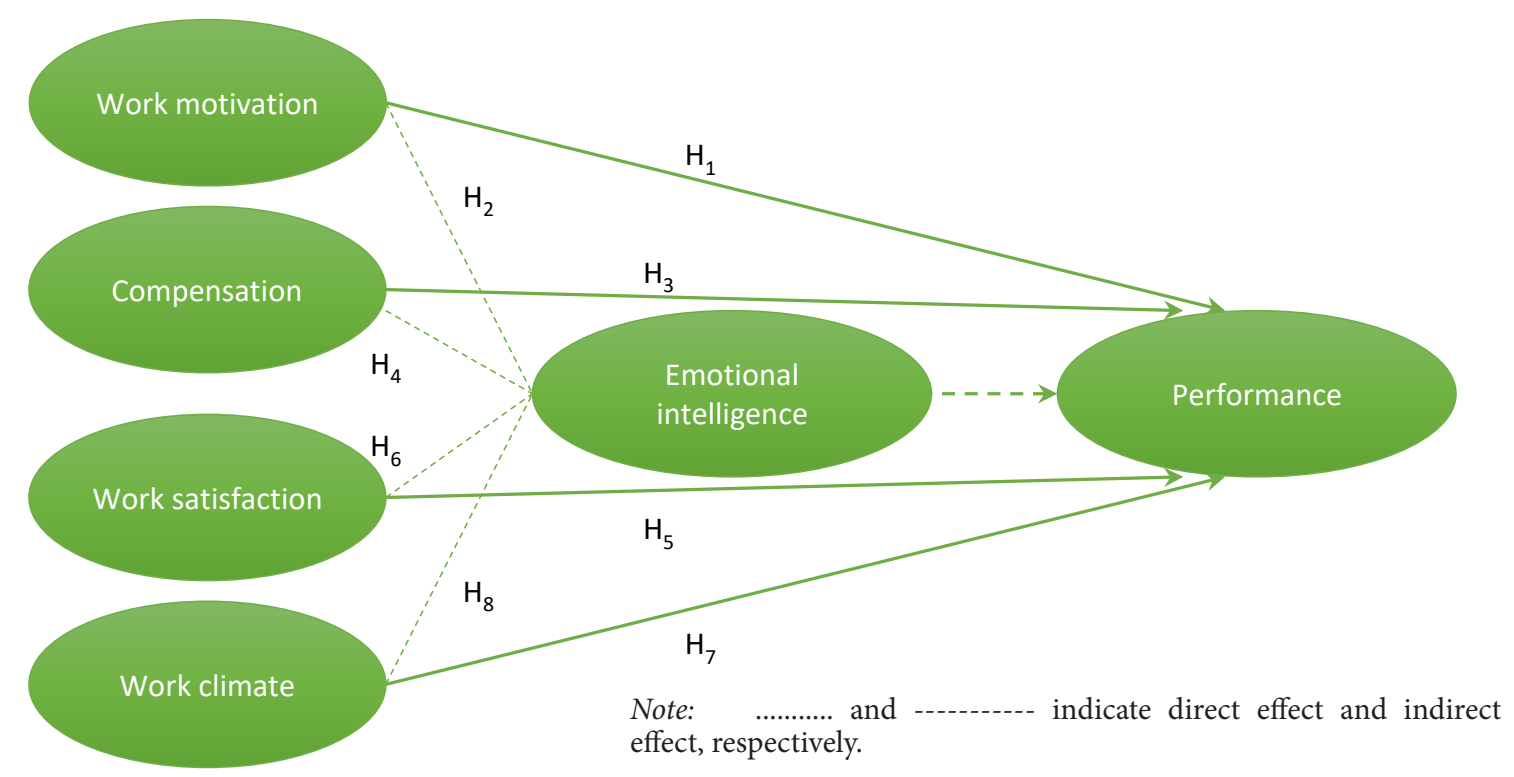

Figure 1. Research's conceptual framework

positive emotional circumstance occurring or resulting from the evaluation of performance. Previous researches have already revealed that work satisfaction significantly affects employees' performance (Munawaroh et al., 2013; Saeed et al., 2013; Muda et al., 2014). However, Diab and Ajlouni (2012) do not find significant correlation between work satisfaction and employees' performance. Given the arguments set up above, we propose the following hypothesis:

H5: Work satisfaction positively affects employees'performance.

Work satisfaction emerges when there is harmony between profession characteristics and employees' expectation. Within this harmony, positive emotional intelligence will emerge, leading to fine performance (Cooper \& Sawaf, 2001). In accordance with Robbins (2002), factors contributing to work satisfaction can be in the form of mentally stimulating work, fair reward, supportive emotional condition, friendly co-workers, and personality-profession harmony. Such conditions will spark one's more productive performance. Based on these elaboration, the following hypothesis is formulated:

H6: Emotional intelligence mediates the relationship between work satisfaction and employees'performance.

\subsection{Work climate, emotional intelligence, and performance}

Work climate will be very supportive to the emergence of optimal performance (Daresh, 1995). By contrast, Syauta et al. (2012) identify work climate as pleasing work atmosphere, which is always expected by every employee so as to create positive performance. However, Munawaroh et al. (2013) and Saeed et al. (2013) do not find empirical support to this contention. Chandrasekar (2011) reveals that work climate holds important role in motivating employees to carry out their duty, which affects their emotional intelligence. The same voice is echoed by Leblebici (2012), who points out that work climate affects employees' performance. Referring to these findings, we propose the following hypothesis:

\section{H7: Work climate positively affects employees' performance.}

According to Meyer (2004), work climate sets one work environment apart from another. He furthers asserts that if work climate is positive and pleasing, coupled with decent emotional intelligence of members, maximum performance will be accommodated. Referring to Agustian (2001), professional work is fraught with various issues and challenges which employees have to deal with, inter alia, tight competition, demanding duty, un- 
conducive work climate, and personal issues with others. Those problems in professional world not only require intellectual competence, but also call for emotional intelligence, to a greater extent. If one is able to solve issues, pertinent to his emotion, in professional world, he will generate better performance. The aforementioned arguments lead to the following hypothesis:

\section{H8: Emotional intelligence mediates the relation- ship between work climate and employees' performance.}

Following the aforementioned theoretical and empirical studies, the conceptual framework of this study is shown in Figure 1.

\section{RESEARCH METHODS}

The population of the present study were all the field officials involved in dealing with DHF as the public servants of Jember Department of Health Affairs. All of the officials were given questionnaire distributed to offices in each sub-district. There are 31 sub-districts in Jember district. The survey was carried out from December 2016 to February 2017. A total of 96 usable questionnaires were analyzed.

The questionnaire applied 5-point Likert scale, which was adapted from related literature and empirical studies. The measurements for work motivation follow Borich (2007), Robins (2006), and Sumarsono (2007). The measurements for compensation adopt David (2006) and Sumarsono (2007). The measurements for work satisfaction follow questionnaires developed by Sumarsono (2007). The measurements for work climate adopt Sumarsono (2007) and Salabi (2014). The measurements for emotional intelligence follow Shapiro (2003) and Mulyani (2008). Lastly, the variable measurements on employees' performance adopt Cahyono (2013), and Micheli and Neely (2010).
To test the hypotheses, the study applied the path analysis. The analysis is used to find out the direct and indirect effect of work motivation, compensation, work satisfaction, and work climate on employees' performance through their emotional intelligence.

\section{RESULTS}

\section{AND DISCUSSION}

\subsection{General description of respondents}

As described previously, the study analyzed 96 usable questionnaires. Most of the respondents were male $(66.7 \%)$. The majority of respondents were 34-44 years old (65.6\%). Most of them hold senior high school or vocational high school (78.1\%). A large number of respondents have been working for 19 to 24 years $(62.5 \%)$.

\subsection{Results of path analysis}

The validity tests on the variables show the correlation values ranging from 0.366 to 0.731 , of which all are statistically significant $(\alpha<0.05)$. Thus, all data have met the validity assumption. The tests on instrument reliability produce the Cronbach's alpha values ranging from 0.790 to 0.955 . These figures are considered to be good. As we use the cutout point of 0.70 , all the data are said to be reliable.

Results of test on direct effect of work motivation, compensation, work satisfaction, and work climate on employees' performance are presented in Table 1. As shown in Table 1, the coefficient of all four independent variables have significant effect on employees' performance. These four variables positively and significantly affect the performance of employees. Thus, hypotheses 1, 3, 5, and 7 are accepted.

Table 1. Results of test on direct effect of variables

\begin{tabular}{|c|c|c|c|}
\hline Hypotheses & Regression model & Direct effect & t-value \\
\hline $\mathrm{H} 1$ & Work motivation $(\mathrm{X} 1) \rightarrow$ Employees' performance $(\mathrm{Y} 2)$ & 0.160 & $3.184^{* * *}$ \\
\hline $\mathrm{H} 3$ & Compensation $(\mathrm{X} 2) \rightarrow$ Employees' performance $(\mathrm{Y} 2)$ & 0.102 & $1.835^{*}$ \\
\hline $\mathrm{H} 5$ & Work satisfaction $(\mathrm{X} 3) \rightarrow$ Employees' performance $(\mathrm{Y} 2)$ & 0.166 & $3.004^{* * *}$ \\
\hline $\mathrm{H} 7$ & Work climate $(\mathrm{X} 4) \rightarrow$ Employees' performance (Y2) & 0.166 & $3.038^{* * *}$ \\
\hline
\end{tabular}

Note: ${ }^{* *}$ and ${ }^{\star}$ denote significance at $1 \%$ and $10 \%$ level, respectively. 
Table 2. Hypotheses testing of indirect effect

\begin{tabular}{l|l|c|c}
\hline Hypotheses & Regression Model & Direct & effect \\
\hline t-value
\end{tabular}

Note: ${ }^{* *}$ and ${ }^{* *}$ denote significance at $1 \%$ and $5 \%$ level, respectively.

Table 2 provides the results of tests on mediating effect of emotional intelligence on the relationship between work motivation, compensation, work satisfaction, work climate and employees' performance. As shown in Table 2, emotional intelligence significantly mediates the relationship between work motivation, compensation, work satisfaction, work climate and employees' performance. Thus, hypotheses $2,4,6$, and 8 are accepted $(p<0.05)$.

The results of test on the direct, indirect, and total effect are displayed in Table 3. It can be seen that each total effect of the independent variable is as follows: work motivation (29.2\%), compensation $(24.5 \%)$, work satisfaction $(32.3 \%)$, and work climate (24.8\%).
Table 3. Results of the tests on direct, indirect, and total effect

\begin{tabular}{|c|c|c|c|}
\hline Regression model & $\begin{array}{l}\text { Direct } \\
\text { effect }\end{array}$ & $\begin{array}{l}\text { Indirect } \\
\text { effect }\end{array}$ & $\begin{array}{l}\text { Total } \\
\text { effect }\end{array}$ \\
\hline $\begin{array}{l}\text { Work motivation }(\mathrm{X} 1) \rightarrow \\
\rightarrow \text { Employees' } \text { performance }(\mathrm{Y} 2)\end{array}$ & 0.160 & 0.132 & 0.292 \\
\hline 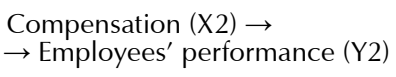 & 0.102 & 0.143 & 0.245 \\
\hline $\begin{array}{l}\text { Work Satisfaction }(\mathrm{X} 3) \rightarrow \\
\rightarrow \text { Employees' performance }(\mathrm{Y} 2)\end{array}$ & 0.166 & 0.157 & 0.323 \\
\hline $\begin{array}{l}\text { Work Climate }(\mathrm{X} 4) \rightarrow \\
\rightarrow \text { Employees' performance }(\mathrm{Y} 2)\end{array}$ & 0.161 & 0.087 & 0.248 \\
\hline
\end{tabular}

In brief, the results of path analysis are shown in Figure 2.

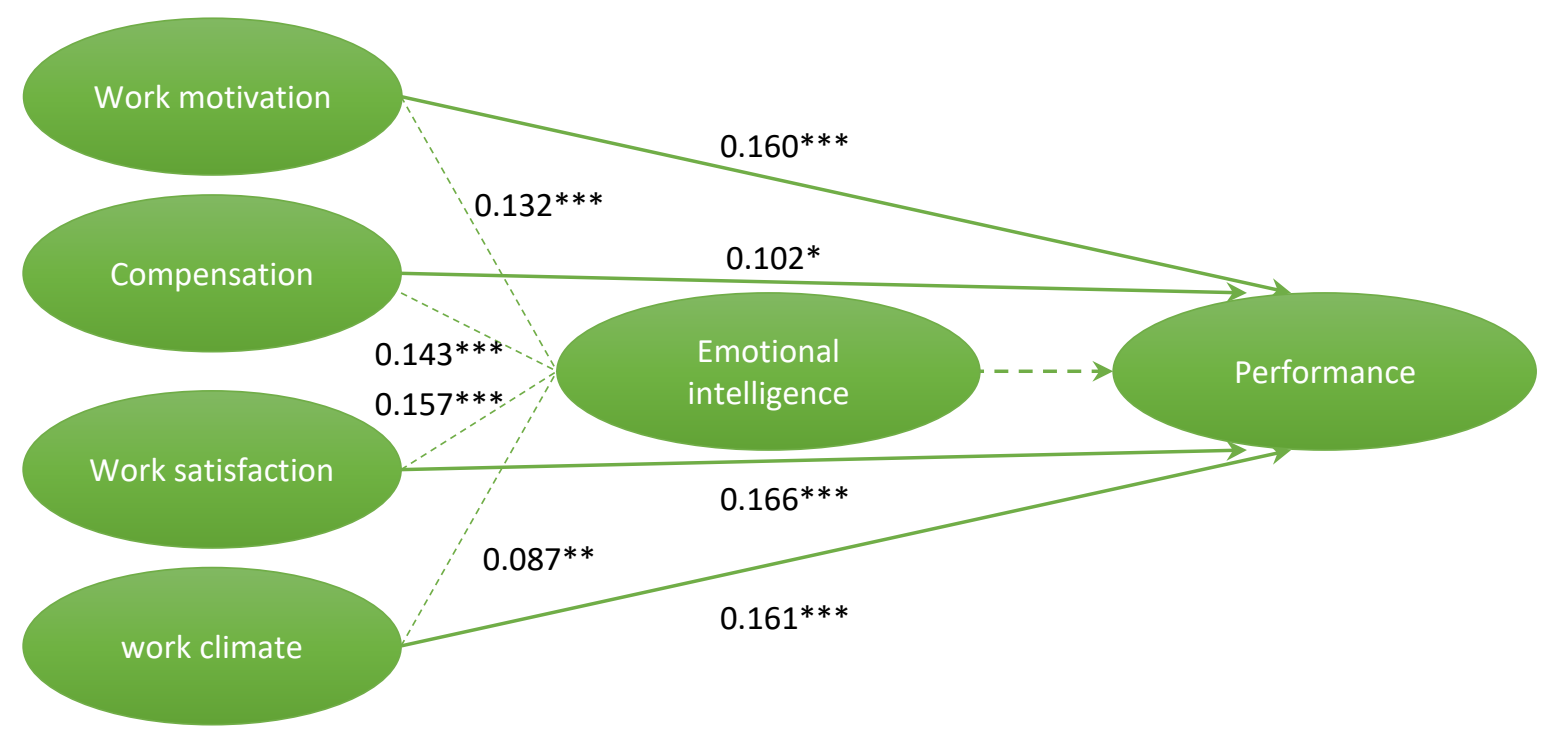

Note: ${ }^{* *},{ }^{* *},{ }^{*}$ denote significance at $1 \%, 5 \%, 10 \%$ levels, respectively.

Figure 2. The path coefficient of direct and indirect effect 


\section{DISCUSSION}

This research has found that work motivation positively and significantly affects employees' performance. This means that the higher the work motivation, the higher will be the performance of the employees. This finding is in support of previous studies (Sulthon, 2009; Elqadri et al., 2013; Shahzadi et al., 2014; Rizal et al., 2014; Manzoor, 2011; Zameer et al., 2014). Thus, we might suggest that good motivation would improve the performance of employees.

Emotional intelligence mediates the influence of work motivation and employees' performance. This means that the indicators of work motivation can escalate employees' performance sustained by emotional intelligence. The indirect effect of work motivation on employees' performance through emotional intelligence is $22.5 \%$, while the direct effect is $12.3 \%$. This means that the indirect effect of work motivation on performance through emotional intelligence is greater than the direct effect of work motivation on performance. This indicates that emotional intelligence mediates the effect of work motivation on employees' performance. We might argue that individual with good decent work optimism will pose the ability to manage his emotion, which will affect his performance. This notion is in line with Patton (1998) who claims that effective activation of emotion will result in established productive relation and work success.

Compensation affects employees' performance at moderate level. This means that the compensation indicators affect employees' performance. As mentioned previously, the samples of the study are government officials and act as the civil servant. We might argue that being a civil servant, he earns fixed salary as stipulated by government's regulation. In the case of field officials, compensation given by the government was already clear. Thus, it could be the case that the employees are working as a form of self-dedication or as a routine activity, rather than solely as a means of obtaining additional compensation.

The study finds that the employees' emotional intelligence statistically mediates the relationship between compensation and employees' perfor- mance. Simply put, compensation indicators can levitate employees' performance with the support of emotional intelligence. The direct effect of compensation on employees' performance reaches $2.6 \%$, whereas the indirect effect of compensation on performance through emotional intelligence is $20.8 \%$. In a sense, the indirect effect of compensation is greater than the direct effect of compensation without the support of emotional intelligence. In other words, emotional intelligence has the power to bridge the effect of compensation on performance.

Work satisfaction is found to have positive effect on employees' performance. This points out that the indicators of work satisfaction can escalate employees' performance. This means that if there are many aspects that are in line with employees' expectations and needs, the higher is the satisfaction, and the better their performance will be, or vice versa (Anoraga, 2005). The findings of the present study corroborate two previous researches which have revealed that work satisfaction is positively and significantly correlated with employees' performance (Munawaroh et al., 2013; Saeed et al., 2013).

The study documents that emotional intelligence mediates the influence of work satisfaction on employees' performance. It means that the indicators of work satisfaction can enhance employees' performance by the effect of emotional intelligence. The direct effect of work satisfaction on employees' performance was $9.8 \%$, while the direct effect of work satisfaction on employees' performance through emotional intelligence was $20.9 \%$. This indicates that the indirect effect of work satisfaction is stronger than is the direct effect on performance without the support of emotional intelligence. It is thus clear that emotional intelligence can improve the influence of work satisfaction and employees' performance. This finding is consistent with Goleman (2006) who states that even though a job remains the same, everyone's work satisfaction will vary all the time, which is dependent on the emotional intelligence with bearing impact on emotional condition and performance.

Work climate has a positive and significant effect on employees' performance. This means that the indicators included in the work climate can esca- 
late employees' performance. This is in line with Wirawan (2007) who asserts that work climate denotes pleasing work atmosphere, and it is expected by every employee so as to pose fine performance. This research finding is consistent with Leblebici (2012) and Saeed et al. (2013) who report that work climate has a positive influence employees' performance.

Emotional intelligence mediates the influence of work climate on employees' performance. In a sense, the indicators of work climate can improve employees' performance due to the presence of emotional intelligence. The direct effect of work climate on performance was $6.4 \%$, while the indirect effect of work climate on employees' performance through emotional intelligence was $13.8 \%$. This means that the indirect effect of work climate is greater than the direct effect on employees' performance. In other words, emotional intelligence can mediate the effect of work climate on employees' performance. This finding is consistent with Agustian (2001) who affirms that professional world possesses various issues and challenges every employee has to handle. Professional world requires not only intellectual competence, but also emotional competence or intelligence, which has appeared more crucial. If one can solve his emotional problems, his work result will increase.

\section{CONCLUSION}

The study is aimed at examining the factors influential to the employees' performance. The tests were performed on a sample of 96 questionnaires generated from the government officials assigned to cope with Dengue Hemorrhagic Fever (DHF) in the district of Jember, Indonesia. The results using path analysis show that emotional intelligence mediates the relationship between work motivation, compensation, work satisfaction, work climate and employees' performance. Independently, work motivation, compensation, work satisfaction, work climate positively affect employees' performance.

Two limitations emerge and worth noting. First, the study is specifically carried out on the local government officials assigned on eradicating the DHF. Thus, the results of the study is very specific and suffer from generalization issue. Second, the field officials were directly in charge of overcoming DHF, but when there was no instruction or recommendation from the policy makers, then the officials could do nothing. Accordingly, future study may be carried out by making comparison between government officials of difference districts or by taking issues on performance assessment by the supervisors.

\section{REFERENCES}

1. Abraham, C., \& Shanley, E. (1997). Social Psychology for Nurse. Sheffield: Edward Arnold.

2. Agustian, A. G. (2001). Rahasia Sukses Membangun Kecerdasan Emosi dan Spiritual: ESQ. Jakarta: Arga.

3. Anoraga, P. (2005). Psikologi Kepemimpinan. Jakarta: Penerbit Rineka Cipta.

4. Cahyono, H. (2013). Relasi birokrasi daerah dan partisipasi publik dalam kinerja pelayanan publik (Dissertation). Universitas Jember: Jember.

5. Caldwell, B. J., \& Spinks, J. M. (1992). Leading the Self Managing School. London: The Falmer Press.
6. Chandrasekar, K. (2011). Workplace environment and its impact on organizational performance in public sector organizations. International Journal of Enterprise Computing and Business Systems, 1(1), 1-20. Retrieved from http://www.ijecbs. com/January2011/N4Jan2011.pdf

7. Cooper, R. K., \& Sawaf, A. (2001). Executive EQ: Emotional Intelligence in Leadership and Organizations. New York: The Barkley Publishing Group.

8. Dann, J. (2002). Emotional Intelligence in a Week. Oxford: Hodder \& Stroughton.

9. Daresh, J. C. (1995). Supervision as a Proactive Process: Concepts and Cases. Illinois: Waveland Press Inc.
10. Diab, S. M., \& Ajlouni, M. T. (2012). The influence of training on employee performance, emotional intelligence and quality of medical services at Jordanian private hospitals. Interdisciplinary Journal of Contemporary Research in Business, 4(6), 117-127. http://dx.doi. org/10.5539/ijbm.v10n2p117

11. Elqadri, Z. M., Wardoyo, D. T. W., \& Priyono (2015). The influence of motivation and discipline work against employee work productivity Tonaan markets. Review of European Studies, 7(12), 173-181. http:// dx.doi.org/10.5539/res.v7n12p59

12. Gibson, J. L., Ivancevich, J. M., Donnelly, J. H., \& Konopaske, R. (2009). Organisations: Behaviour, 
Structure, Processes (14 ${ }^{\text {th }}$ Edition). New York: McGraw- Hill.

13. Goleman, D. (2006). Emotional Intelligence: Why It Can Matter More than IQ. New York: Bantam Books.

14. Himanshu., Goel, M., \& Sharma, C. B. (2017). Emotional intelligence as a predictor of job performance and satisfaction in II/ITES Sector of India. International Journal of Management, 8(2), 260-267. Retrieved from http:// www.iaeme.com/ijm/issues.as$\mathrm{p}$ ?JType $=I J M \& V$ Type $=8 \& I$ Type $=2$

15. Khan, A. H., Nawaz, M. M., Aleem, M., \& Hamed, W. (2012). Impact of job satisfaction on employee performance: An empirical study of autonomous Medical Institutions of Pakistan. African Journal of Business Management, 6(7), 2697-2705. Retrieved from http://www.academicjournals.org/ journal/AJBM/article-abstract/ DF6BEC626842

16. Leblebici, D. (2012). Impact of workplace atmosphere on employees' performance: Case study of a bank in Turkey. Journal of Business Economics Finance, 1(1), 38-49. Retrieved from http://dergipark.ulakbim.gov.tr/jbef/article/ view/5000075821/5000070122

17. Luthans, F. (2011). Organizational Behavior (12 ${ }^{\text {th }}$ Ed.). New York: McGraw Hill.

18. Manzoor, Q. A. (2011). Impact of employees motivation on organizational effectiveness. European Journal of Business and Management, 3(3), 36-44. Retrieved from http:// www.iiste.org/Journals/index.php/ EJBM/article/view/265/150

19. Martin, A. D. (2000). Aplikasi EQ Based HR Management System. Yogyakarta: Amara Books.

20. Micheli, P., \& Neely, A. (2010). Performance measurement in the public sector in England: Searching the golden thread. Public Administration Review, 70(4), 591-600. http://dx.doi.org/10.1111/j.15406210.2010.02180.x.

21. Mindarti, L. I. (2005). Revolusi Administrasi Publik: Aneka Pendekatan dan Teori. Malang: Partner Press.
22. Muda, I., Rafiki, A., \& Harahap, M. R. (2014). Factors influencing employee performance: A study on the Islamic banks in Indonesia. International Journal of Business and Social Science, 5(2), 73-80. Retrieved from http://ijbssnet. com/journals/Vol_5_No_2_February_2014/9.pdf

23. Mulyani, S. (2008). Analisis pengaruh faktor-faktor kecerdasan emosi terhadap komunikasi interpersonal perawat dengan pasien di unit rawat inap RSJD Dr. Amino Gondohutomo Semarang Tahun 2008 (Master Thesis). Universitas Diponegoro, Semarang, Indonesia. Retrieved from http://eprints.undip.ac.id/18295/1/Sri_Mulyani.pdf

24. Munawaroh, A., Riantoputra, C. D. S., \& Marpaung, S. B. (2013). Factors influencing individual performance in an Indonesian government office. The South East Asian Journal of Management, 5(2), 51-60. Retrieved from: http:// journal.ui.ac.id/index.php/tseajm/ article/viewFile/2051/1560

25. Nawawi, H. (2005). Manajemen Sumber Daya Manusia. Yogyakarta: Gajah Mada University Press.

26. Obicci, P. A. (2015). Effects of ethical leadership on employee performance in Uganda. Net Journal of Business Management, 3(1), 1-12. Retrieved from http:// www.netjournals.org/pdf/ NJBM/2015/1/14-024.pdf

27. Patton, P. (1998). Emotional Intelligence in the Workplace. Jakarta: Pustaka Delaprata.

28. Purba, A. (1999). Emotional Intelligence: Seri Ayah Bunda. Jakarta: Dian Raya.

29. Rizal, M., Idrus, M. S., Djumahir, \& Mintarti, R. (2014). Effect of compensation on spirit at work, emotional intelligence and performance. International Journal of Business and Management Invention, 3(2), 64-79. Retrieved from http://www.ijbmi.org/papers/ Vol(3)2/Version-1/I0321064079.pdf

30. Robbins, S. P. (2002). Organizational Behavior: Concepts, Controversies and Application $\left(10^{\text {th }}\right.$ Ed.). New Jersey: Prentice Hall.

31. Saeed, R., Mussawar, S., Rab Nawaz Lodhi, R. N., Iqbal, A.,
Nayab, H. H., \& Yaseen, S. (2013). Factors affecting the performance of employees at work place in the banking sector of Pakistan. MiddleEast Journal of Scientific Research, 17(9), 1200-1208. Retrieved from https://www.idosi.org/mejsr/mejsr17(9)13/1.pdf

32. Salabi (2014). Hubungan Keterampilan Manajerial Kepala Sekolah, Komunikasi Organisasi, Pengendalian Konflik dan Iklim Organisasi dengan Keefektifan Organisasi Madrasah Aliyah Negeri di Propinsi Kalimantan Selatan. Banjarmasin, IAIN Antasari Press.

33. Shafie, B., Baghersalimi, S., \& Barghi, V. (2013). The relationship between leadership style and employee performance (Case Study of real estate registration organization of Tehran Province). Singaporean Journal of Business Economics and Management Studies, 2(3), 21-29. Retrieved from http://www.singaporeanjbem. com/pdfs/SG_VOL_2_(5)/3.pdf

34. Shahzadi, I., Javed, A., Pirzada, S. S., Nasreen, S., \& Khanam, F. (2014). Impact of employee motivation on employee performance. European Journal of Business and Management, 6(23), 159-166. Retrieved from http://www.iiste.org/ Journals/index.php/EJBM/article/ view/14794/15276

35. Smith, H. W. (1975). Job Satisfaction. New Jersey USA: PrenticeHall, Inc. Englewood Cliffs.

36. Sulthon (2009). Membangun Semangat Kerja Guru. Yogyakarta: LeksBang Pressindo.

37. Sumarsono, R. (2007). Hubungan tunjangan kinerja, keikutsertaan dalam pengambilan keputusan, suasana kerja dengan semangat kerja guru di Kabupaten Jember (Dissertation). Universitas Brawijaya, Malang. Indonesia.

38. Suryabrata, S. (2006). Psikologi Kepribadian. Jakarta: PT Raja Grafindo Persada.

39. Sy, T., Tram, S., \& O’Hara, L. A. (2006). Relation of employee and manager emotional intelligence to job satisfaction and performance. Journal of Vocational Behavior, 68(3), 461-473. https://doi. org/10.1016/j.jvb.2005.10.003 
40. Syauta, J. H., Troena, E. A., Setiawan, M., \& Solimun (2012). The influence of organizational culture, organizational commitment to job satisfaction and employee performance (Study at municipal waterworks of Jayapura, Papua Indonesia). International Journal of Business and Management Invention, 1(1), 69-76. Retrieved from http://www.ijbmi.org/papers/ Vol(1)1/H116976.pdf

41. Vratskikh, I., Masa'deh, R. W., AlLozi, M., \& Maqableh, M. (2016).
The impact of emotional intelligence on job performance via the mediating role of job satisfaction. International Journal of Business and Management, 11(2), 69-91. http://dx.doi.org/10.5539/ijbm. v11n2p69

42. Wirawan (2007). Budaya dan Iklim Kerja Teori dan Aplikasi Penelitian. Jakarta: Salemba Empat.

43. Yamoah, E. E. (2013). Relationship between compensation and employee productivity. Singapor- ean Journal of Business Economics and Management Studies, 2(1), 110-114. Retrieved from http:// www.singaporeanjbem.com/pdfs/ SG_VOL_2_(1)/10.pdf

44. Zameer, H., Ali, S., Nisar, W., \& Amir, M. (2014). The impact of the spirit at work on the employee performance in beverage industry of Pakistan. International Journal of Academic Research in Accounting, Finance and Management Science, 4(1), 293-298. http://dx.doi. org/10.6007/IJARAFMS/v4-i1/630 